\title{
HER2 gene amplification in patients with prostate cancer: Evaluating a CISH-based method
}

\author{
NAZANIN SHARIFI $^{1 *}$, ARASH SALMANINEJAD $^{1,2^{*}}$, SAMIRA FERDOSI $^{1}$, ABOLFAZL NESAEI BAJESTANI $^{3}$, \\ MALIHE KHALEGHIYAN ${ }^{1,4}$, MEHRDAD ASGHARI ESTIAR ${ }^{4}$, MANSOUR JAMALI $^{5}$, \\ MOHAMMAD REZA NOWROOZI ${ }^{6}$ and ABBAS SHAKOORI ${ }^{1,4}$ \\ ${ }^{1}$ Department of Medical Genetics, Cancer Institute of Iran, Tehran University of Medical Sciences, Tehran 1419733141; \\ ${ }^{2}$ Genetic Research Center, Student Research Committee, Department of Medical Genetics, Faculty of Medicine, \\ Mashhad University of Medical Sciences, Mashhad 9177948564; ${ }^{3}$ Department of Medical Genetics, \\ Ayatollah Madani Hospital, Gonabad University of Medical Sciences, Gonabad 9698154813; \\ ${ }^{4}$ Department of Medical Genetics, Tehran University of Medical Sciences; ${ }^{5}$ Department of Pathology, \\ Imam Khomeini Hospital, Tehran University of Medical Sciences; ${ }^{6}$ Uro Oncology Research Center, \\ Tehran University of Medical Sciences, Tehran 1471613151, Iran
}

Received December 4, 2015; Accepted July 12, 2016

DOI: $10.3892 / \mathrm{ol} .2016 .5235$

\begin{abstract}
Prostate cancer (PCa) is one of the most widespread malignancies in the world. The role of the human epidermal growth factor receptor 2 (HER2) in the pathogenesis and progression of human PCa remains poorly understood. In contradiction with breast cancer, studies on HER2 overexpression and gene amplification in PCa have produced varying results, although the HER2 oncogene has been implicated in the biology of numerous tumor types, and serves as a prognostic marker and therapeutic target in breast cancer. Technical challenges are considered the main reasons for data discrepancies. Amplification of the HER2 gene has previously been reported in $\mathrm{PCa}$, in which it was associated with tumor progression. The present study aimed to evaluate the prevalence and clinical significance of HER2 amplification in $\mathrm{PCa}$. A total of 32 biopsy samples obtained from human prostate adenocarcinomas were evaluated by chromogenic in situ hybridization (CISH) to determine the frequency of patients with HER2 gene amplifications. High copy numbers of HER2 were detected in 19 of the prostate tumors analyzed. The results of the present study suggested that, in patients without
\end{abstract}

Correspondence to: Dr Abbas Shakoori, Department of Medical Genetics, Cancer Institute of Iran, Tehran University of Medical Sciences, Keshavarz Blvd, Poursina Street, Tehran 1419733141, Iran E-mail: shakooria@tums.ac.ir

\section{${ }^{*}$ Contributed equally}

Abbreviations: PCa, prostate cancer; HER2, human epidermal growth factor receptor 2; CISH, chromogenic in situ hybridization; PSA, prostate specific antigen; FISH, florescence in-situ hybridization

Key words: prostate cancer, human epidermal growth factor receptor 2, amplification, gene, chromogenic in situ hybridization amplification of HER2, high levels of prostate-specific antigen or a high Gleason score were not significantly correlated with a high pathologic stage. Furthermore, amplification levels of the HER2 gene were directly associated with pathologic stage in patients with PCa. Therefore, the potential use of HER2 as a prognostic factor or therapeutic target for PCa warrants further study.

\section{Introduction}

Prostate cancer (PCa), a common non-skin, sex-limited cancer, is the second cause of cancer-associated mortality (after lung cancer) in the USA $(1,2)$ and the second most prevalent cancer among Iranian men (3). Worldwide, PCa is the second most commonly diagnosed cancer and, according to the International Agency for Research on Cancer's GLOBOCAN 2012 (4) database, it is the fifth leading cause of cancer-associated mortality in men. The incidence of PCa is increasing worldwide, although there is a marked variation in its incidence among different regions (5). The clinical configuration of $\mathrm{PCa}$ has noticeably altered over the past few years. As a localized disease, it is easily treated by radical radiation therapy or a prostatectomy; however, if the tumor becomes malignant, it transforms into a life-threatening disease (6).

The progression and application of novel high-resolution technologies has enhanced the detection of genomic alterations, enabling elucidation of the complex nature and heterogeneity of PCa (7). The differentiation of PCa tumors is typically based on the serum expression levels of prostate-specific antigen (PSA), although, in certain cases, PSA levels do not accurately reflect tumor burden (8). Previous studies have identified a number of genetic, epigenetic and environmental risk factors for $\mathrm{PCa}$ (9-11). Among them, genetic aberrations and chromosomal changes have been suggested to serve a significant role in the development and progression of $\mathrm{PCa}$ (12). At present, >50 PCa susceptibility loci have been identified 
using genome-wide association studies $(13,14)$. The emerging picture of the genomic complexity of $\mathrm{PCa}$ includes frequent large-scale genomic rearrangements $(15)$, gene fusions $(16,17)$, genetic deletions (15) and gene amplifications (18).

Gene amplification, which may occur due to an increase in copy number of certain regions of chromosomes, has been identified in several malignancies, including PCa $(18,19)$. Previous studies have reported that the genetic duplication of various genes was associated with PCa malignancy, including androgen receptor (20), enhancer of zeste homolog 2 (21), eukaryotic translation initiation factor 3 (22), calcium-activated potassium channel subunit $\alpha-1$ (23), minichromosome maintenance complex component 7 (24), prostate leucine zipper (25) and hypoxia-inducible factor 1 (26).

Human epidermal growth factor receptor 2 (HER2) is a member of the class I receptor tyrosine kinase family and has substantial homology to epidermal growth factor receptor, HER3 and HER4 (27). HER2 overexpression and/or gene amplification occur in a variety of human epithelial tumors, particularly in breast cancer, in which the receptor and its gene have been investigated extensively (28). Conversely, the significance of HER2 overexpression and gene amplification in PCa remains controversial. Previous studies have used immunohistochemical analysis to evaluate HER2 protein expression in primary prostate specimens, demonstrating expression rates ranging from $0-100 \%$ (29-31). Therefore, the exact prevalence of HER2 gene amplifications in primary $\mathrm{PCa}$ remains unknown, likely owing to the wide range of antibodies and methods used in these studies $(32,33)$.

The HER2/neu proto-oncogene, which is located on chromosome 17 (OMIM: 164870), encodes a transmembrane tyrosine kinase growth factor receptor (34), whose overexpression was shown to be involved in the development of various types of human cancer, including non-small-cell lung cancer, colon cancer and breast cancer, and may have prognostic value $(35,36)$. Apparent chromosome 17 polysomy, defined by increased chromosome enumeration probe 17 (CEP17) signal number, is a common genetic aberration in breast cancer and represents an alternative mechanism for increasing HER2 copy number (37). However, the prognostic value of HER2/neu amplification in PCa remains controversial (38).

Chromosomal aberrations associated with $\mathrm{PCa}$ have been evaluated using various techniques, including classical cytogenetics (39), loss of heterozygosity analysis (40), fluorescence in situ hybridization (FISH) (41) and, most commonly, comparative genomic hybridization (CGH) (42). Although the criteria for amplification have varied between studies, they have implicated several chromosomal regions, such as $6 \mathrm{q}, 8 \mathrm{p}$, $10 \mathrm{q}, 13 \mathrm{q}, 16 \mathrm{q}$ and $\mathrm{Xq}$, that may harbor genes involved in the tumorigenesis of PCa $(24,43)$.

The present study aimed to investigate the frequency of HER2 amplification in prostate biopsies from Iranian (Tehran province) patients using chromogenic in situ hybridization (CISH), which permits the rapid analysis of a large number of tumors (44). Although the FISH method has been verified for the histological analysis of tissues, the evaluation of tumor morphology using FISH is challenging and the fluorescence fades quickly (45). These limitations may be overcome by CISH, which enables visualization of the amplification product along with morphological features (46).
Furthermore, CISH technology is superior to high-throughput HER2 genetic testing due its speed, although FISH remains the method of choice for rapid low-throughput HER2 genetic testing.

\section{Materials and methods}

Clinical specimens. The present study was approved by the Ethics Committee of Tehran University of Medical Sciences (Tehran, Iran). Suitable patients from the oncology wards or outpatient clinics of Imam Khomeini Hospital (Tehran, Iran) were approached for participation in the study, and informed consent was obtained. Inclusion criteria for the study were a PSA level of $>4$, a diagnosis of progressive prostate cancer, an age of $>54$ years, a Gleason score of $>2$ (47) and the male gender. Formalin-fixed, paraffin-embedded (FFPE) specimens were obtained from 32 consecutive PCa patients who underwent surgery between May 2013 and February 2015. Adjacent normal tissue was used as a control. To account for tumor heterogeneity, a minimum of 3 cylindrical core biopsies, $0.6 \mathrm{~mm}$ in diameter, were harvested from different regions of each tumor. A total of 15 tissue sections (2-mm thick) were sliced from each paraffin-embedded tumor block and mounted onto glass slides. The first tissue section was stained with hematoxylin and eosin and visualized under a light microscope to ascertain the region of interest. In all cases, a serum sample was measured by Elecsys ${ }^{\circledR}$ total PSA and free PSA kits (Roche Diagnostics, Basel, Switzerland).

Pathological stage. The stage (extent) of prostate cancer is one of the most important factors in choosing treatment options and predicting prognosis. The stage is based on the prostate biopsy results (including the Gleason score), the blood PSA level at the time of diagnosis, the results of any other exams or tests that were performed to determine metastasis and the pathological stage post-surgery. There are 4 categories for describing the local extent of a prostate tumor, ranging from T1 to T4 (48).

CISH.CISH was performed according to a previously described protocol (49) with minor modifications. Briefly, 2-mm thick archival FFPE tissue sections were deparaffinized and dehydrated in $0.1 \mathrm{~mol} / 1$ Tris- $\mathrm{HCl}(\mathrm{pH} 7.3)$ in a temperature-controlled microwave oven at $92^{\circ} \mathrm{C}$ for $10 \mathrm{~min}$. Subsequently, the sections were allowed to cool for $20 \mathrm{~min}$, followed by washing with phosphate-buffered saline (PBS) for 3-4 min at $37^{\circ} \mathrm{C}$. The slides were then dehydrated with graded ethanol, rinsed in saline sodium citrate $(\mathrm{pH}$ 7.2) for $5 \mathrm{~min}$ at room temperature and air-dried. Enzymatic digestion was performed by incubating the sections with pepsin solution (dilution, 100:1) for 10 to $15 \mathrm{~min}$ at room temperature. The slides were then washed with PBS and dehydrated with graded ethanol. The ready-to-use digoxigenin-labeled HER2/neu probe (Zyto Dot 2C SPEC HER2/CEN 17 Probe kit; Zyto Vision GmbH, Bremerhaven, Germany) was applied onto the slides. The presence of certain nucleic acid sequences in cells or tissue can be detected with in situ hybridization using labeled DNA probes. The hybridization results in duplex formation of sequences present in the test object and the specific gene probe. The ZytoDot 2C SPEC HER2/CEN 17 
Table I. Prostate cancer patients with or without HER2 amplification.

\begin{tabular}{|c|c|c|c|c|c|c|c|c|}
\hline Patient ID & Age & Situation & PSA & Pathologic grade & Gleason score & Green signal & Red signal & Green/red \\
\hline P-709 & 55 & $\mathrm{~L}$ & 5.1 & 2 & 4 & 271 & 116 & 2.31 \\
\hline P-436 & 82 & $\mathrm{R}$ & 8.1 & $3 b$ & 5 & 410 & 134 & 3.05 \\
\hline P-1139 & 56 & $\mathrm{~L}$ & 8.2 & 2 & 4 & 201 & 83 & 2.42 \\
\hline P-100 & 65 & $\mathrm{~L}$ & 9.2 & $3 a$ & & 355 & 130 & 2.73 \\
\hline P-326 & 61 & $\mathrm{~L}$ & 9.3 & $4 b$ & 6 & 296 & 90 & 3.28 \\
\hline P-435 & 82 & $\mathrm{R}$ & 6.1 & $3 a$ & 5 & 168 & 75 & 2.24 \\
\hline P-1101 & 67 & $\mathrm{R}$ & 195 & $4 b$ & 7 & 401 & 134 & 2.99 \\
\hline P-564 & 66 & $\mathrm{~L}$ & 10.9 & $3 a$ & 6 & 201 & 68 & 2.95 \\
\hline P-62 & 69 & $\mathrm{~L}$ & 32.8 & $3 a$ & 5 & 278 & 116 & 2.39 \\
\hline P-27 & 83 & $\mathrm{~L}$ & 9.3 & $3 a$ & 5 & 180 & 71 & 2.53 \\
\hline P-63 & 61 & $\mathrm{R}$ & 14.8 & $3 a$ & 5 & 214 & 95 & 2.25 \\
\hline P-425 & 82 & $\mathrm{~L}$ & 16.2 & $3 a$ & 5 & 220 & 75 & 2.93 \\
\hline P-599 & 75 & $\mathrm{R}$ & 74.3 & $4 b$ & 7 & 224 & 88 & 2.54 \\
\hline P-13 & 83 & $\mathrm{R}$ & 16.4 & $4 b$ & 6 & 485 & 181 & 2.67 \\
\hline P-68 & 70 & $\mathrm{~L}$ & 156.2 & $4 b$ & 7 & 182 & 73 & 2.49 \\
\hline P-80 & 70 & $\mathrm{R}$ & 9.2 & 4 & 6 & 465 & 193 & 2.41 \\
\hline P-69 & 66 & $\mathrm{~L}$ & 19.2 & 4 & 7 & 459 & 186 & 2.46 \\
\hline P-137 & 78 & $\mathrm{R}$ & 20.8 & 4 & 6 & 150 & 68 & 2.22 \\
\hline P-162 & 75 & $\mathrm{~L}$ & 33.1 & 4 & 6 & 421 & 166 & 2.53 \\
\hline P-691 & 65 & $\mathrm{~L}$ & 4.95 & 2 & 4 & 444 & 256 & 1.73 \\
\hline P-993 & 61 & $\mathrm{~L}$ & 69.8 & $4 b$ & 8 & 212 & 165 & 1.28 \\
\hline P-1084 & 82 & $\mathrm{~L}$ & 45.7 & $4 a$ & 7 & - & - & - \\
\hline P-806 & 78 & $\mathrm{~L}$ & 6.1 & $4 b$ & 7 & 229 & 112 & 2.04 \\
\hline P-856 & 80 & $\mathrm{~L}$ & 78.3 & $4 a$ & 6 & 240 & 123 & 1.95 \\
\hline P-27 & 83 & $\mathrm{~L}$ & 8.1 & $3 a$ & 5 & 221 & 110 & 2.00 \\
\hline P-150 & 68 & $\mathrm{R}$ & 8.9 & $4 b$ & 6 & - & 120 & - \\
\hline P-439 & 82 & $\mathrm{~L}$ & 6.1 & $3 a$ & 5 & 160 & 79 & 2.02 \\
\hline P-174 & 57 & $\mathrm{R}$ & 5.5 & 2 & 4 & 112 & 60 & 1.80 \\
\hline P-12 & 71 & $\mathrm{~L}$ & 18.6 & $3 c$ & 5 & 478 & 233 & 2.05 \\
\hline P-37 & 77 & $\mathrm{~L}$ & 140.1 & 4 & 6 & 110 & 59 & 1.86 \\
\hline P-83 & 58 & $\mathrm{~L}$ & 7.3 & 4 & 5 & 165 & 86 & 1.91 \\
\hline P-164 & 74 & $\mathrm{R}$ & 4.4 & 4 & 5 & 596 & 281 & 2.12 \\
\hline
\end{tabular}

HER2 amplification was considered when the green/red ratio was $>2.2$. HER2, human epidermal growth factor receptor 2; PSA, prostate-specific antigen; L, left; R, right.

Table II. P-values for the associations between the mean age, serum levels of PSA, green/red ratio and Gleason score of patients without human epidermal growth factor receptor 2 amplification.

\begin{tabular}{lcccc}
\hline Parameter & Age & PSA & Green/red & Gleason \\
\hline Age & - & 0.23 & 0.046 & 0.253 \\
PSA & - & - & 0.228 & 0.004 \\
Green/red & - & - & - & 0.941 \\
\hline
\end{tabular}

PSA, prostate-specific antigen.

Probe kit uses the ZytoDot 2C SPEC HER2/CEN 17 Probe EmaNOF. The probe contains digoxigenin-labeled polynucleotides, which target sequences of the HER2 gene and
DNP-labeled polynucleotides, which target alpha-satellites of the centromere of chromosome 17. Duplex formation of the labeled probe can be visualized using primary (un-marked) antibodies, which are detected by secondary polymerized enzyme-conjugated antibodies. The enzymatic reactions of the substrates leads to the formation of strong permanent red and green signals that can be visualized by light microscopy using a 40X dry lens. The slides were denatured on a hot plate for $3 \mathrm{~min}$ and hybridization was performed overnight at $37^{\circ} \mathrm{C}$. Following hybridization, the slides were washed with $0.5 \mathrm{ml}$ standard saline citrate for $5 \mathrm{~min}$ at $75^{\circ} \mathrm{C}$, followed by three washes with PBS containing $0.2 \%$ Tween-20 at room temperature. Prostate tissue sections were lightly counterstained with hematoxylin then embedded, and the tissues were analyzed under a light microscope. Amplification was defined when the HER2/chromosome 17 centromere (CEP17) ratio was $>2.2$. 
Table III. Associations among tumor position, pathological stage, age, serum levels of PSA, green/red ratio and Gleason score in patients without human epidermal growth factor receptor 2 amplification.

\begin{tabular}{lcccc}
\hline Parameter & Age & PSA & Green/red & Gleason score \\
\hline Tumor position & & & & \\
Left & $73.7 \pm 9.3$ & $38.4 \pm 45.2$ & $1.88 \pm 0.23$ & $5.8 \pm 1.2$ \\
Right & $66.33 \pm 8.61$ & $6.1 \pm 2.5$ & $1.97 \pm 0.16$ & $5 \pm 1$ \\
P-value & 0.15 & 0.009 & 0.453 & 0.240 \\
Pathologic stage & & & \\
2 & $61 \pm 5.6$ & $5.22 \pm 0.38$ & 4 & 1.76 \\
3a & $82 \pm 0.70$ & $7 \pm 1.41$ & 2 & 5 \\
3c & 71 & 18.6 & 2.05 & 5 \\
4 & $69.66 \pm 10.21$ & $50.43 \pm 77.58$ & $1.96 \pm 0.14$ & $5.33 \pm 0.5$ \\
4a & $81 \pm 0.71$ & $62 \pm 23.05$ & 1.95 & $6 \pm 0.71$ \\
4b & $69 \pm 8.54$ & $28.27 \pm 36.00$ & $1.66 \pm 0.54$ & $7 \pm 1$ \\
P-value & 0.142 & 0.749 & 0.873 & 0.057 \\
\hline
\end{tabular}

Data are presented as the mean \pm standard deviation. PSA, prostate-specific antigen.

Table IV. P-values for the associations between the age, serum levels of PSA, green/red ratio and Gleason score of patients with human epidermal growth factor receptor 2 amplification.

\begin{tabular}{lcccc}
\hline Parameter & Age & PSA & Green/red & Gleason \\
\hline Age & - & 0.248 & 0.571 & 0.522 \\
PSA & - & - & 0.404 & $<0.001^{\mathrm{a}}$ \\
Green/red & - & - & - & 0.62 \\
\hline
\end{tabular}

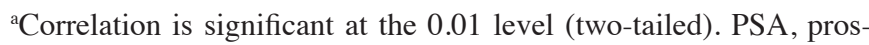
tate-specific antigen.

Statistical analysis. Red/green signals were counted manually. Data analysis was performed using SPSS software version 18 (SPSS, Inc., Chicago, IL, USA). Scale variables were analyzed for normality using the Kolmogorov-Smirnov test. Group comparisons of continuous variables were conducted using the independent-samples $t$-test. When a variable was non-normally distributed, Mann-Whitney or Kruskal-Wallis non-parametric tests were performed. GraphPad Prism version 5.0 software for Windows (GraphPad Software, La Jolla, CA, USA) was used to illustrate the data through graphs. Data are expressed as the mean \pm standard deviation. $\mathrm{P}<0.05$ was considered to indicate a statistically significant difference.

\section{Results}

Associations among age, PSA levels, green/red ratios and Gleason scores in patients with or without HER2 amplification. For statistical analysis, patients were divided into two groups consisting of patients with or without HER2 amplification. Variables were assessed within each group and the results are presented in Tables I-III. The demographic data of patients with PCa with and without HER2 amplification are shown in Table I. There were no associations among the serum levels of PSA, green/red ratios (Fig. 1) or Gleason scores in patients without HER2 amplification.

Amplification levels of the HER2 gene are directly associated with pathological stage in patients with PCa. There was a weak association between the green/red ratio and age in patients without HER2 amplification $(\mathrm{P}=0.046$; Table II), thus suggesting that younger patients exhibited a lower tendency for HER2 amplification. In addition, a positive correlation $(\mathrm{P}=0.004)$ was observed between the serum levels of PSA and Gleason score (Table II). The associations between the green/red ratio and PSA levels or Gleason score were not significant $(\mathrm{P}=0.228$ and 0.941 , respectively; Table II).

For the analysis, patients were divided into two separate groups based on the level of HER2 gene amplification (i.e., with and without amplification). The first group consisted of 19 patients and the second group consisted of 13 patients. A high level of HER2 gene amplification was considered when the HER2/CEP17 ratio was $>2.2$ (Fig. 1).

The mean ages were 73.7 and 63.3 years for patients with left- and right-side tumors, respectively, which were not significantly different $(\mathrm{P}=0.15$; Table III). With the exception of the serum levels of PSA $(\mathrm{P}=0.009)$, there were no significant differences in any of the parameters (green/red ratio and Gleason score) between patients with left- and right-sided tumors. The mean Gleason score among patients was 5, and the Gleason score showed no association with the pathologic stage $(\mathrm{P}=0.303$; Table III). The tumors were composed of different Gleason scores, but were between stages T2 and T5 (Table III). Similar to the patients without HER2 amplification, there was a significant association between the Gleason score and serum levels of PSA in patients with HER2 amplification $(\mathrm{P}<0.001$; Table IV). However, there was no significant association between the other parameters in patients with HER 2 amplification ( $\mathrm{P}>0.05$; Table IV). The tumor position was not significantly associated with the mean age, PSA levels, green/red ratio or Gleason score of patients with HER2 
Table V. Associations among tumor position, pathologic stage, age, serum levels of PSA, green/red ratio and Gleason score in patients with human epidermal growth factor receptor 2 amplification.

\begin{tabular}{|c|c|c|c|c|}
\hline Parameter & Age & PSA & Green/red & Gleason score \\
\hline \multicolumn{5}{|c|}{ Tumor position } \\
\hline Left & $68.0 \pm 9.24$ & $28.4 \pm 43.5$ & $2.64 \pm 0.3$ & $5.5 \pm 1.0$ \\
\hline Right & $74.75 \pm 8.0$ & $43 \pm 65.25$ & $2.55 \pm 0.33$ & $5.89 \pm 0.83$ \\
\hline P-value & 0.75 & 0.643 & 0.382 & 0.290 \\
\hline \multicolumn{5}{|c|}{ Pathologic stage } \\
\hline 2 & $55.5 \pm 0.71$ & $6.55 \pm 2$ & $2.36 \pm 0.08$ & 4 \\
\hline $3 a$ & $73.83 \pm 9.67$ & $15 \pm 9.45$ & $2.58 \pm 0.3$ & $5.17 \pm 0.4$ \\
\hline $3 b$ & 82 & 8 & 3.05 & 5 \\
\hline $4 a$ & $72.25 \pm 5.32$ & $20.55 \pm 9.7$ & $2.4 \pm 0.15$ & $6.25 \pm 0.5$ \\
\hline $4 b$ & $71.2 \pm 8.32$ & $90.24 \pm 83.04$ & $2.79 \pm 0.33$ & $6.6 \pm 0.55$ \\
\hline P-value & 0.095 & 0.078 & 0.123 & 0.002 \\
\hline
\end{tabular}

Data are presented as the mean \pm standard deviation. PSA, prostate-specific antigen.

$\mathbf{A}$

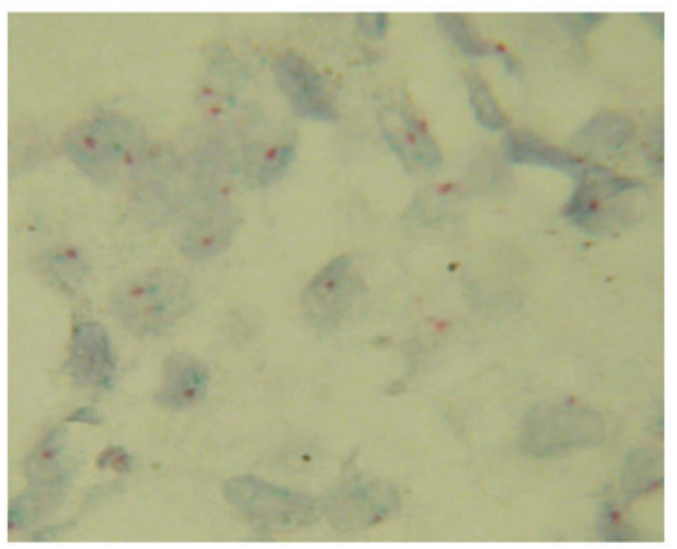

B

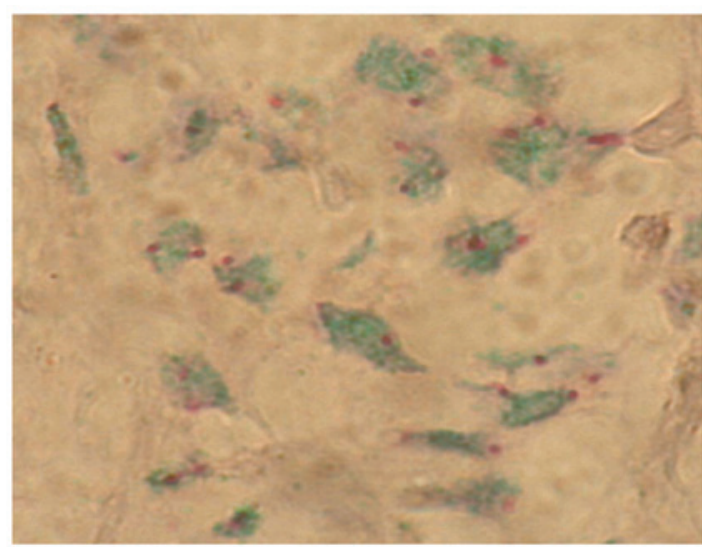

Figure 1. Human epidermal growth factor receptor $2 /$ neu oncogene gene status in prostate carcinomas, as detected by chromogenic in situ hybridization. Green signals correspond to HER2, and red signals correspond to (magnification, x100). (A) HER2 gene non-amplified. (B) HER2 gene amplified. A high level of HER2 gene amplification was detected when the HER2/CEP17 ratio was $>2.2$. HER2, human epidermal growth factor receptor 2; CEP17, chromosome 17 centromere.

amplification, although a significant correlation was observed between the Gleason score and pathologic stage $(\mathrm{P}=0.002$; Table V).

\section{Discussion}

DNA ploidy has been accepted as a significant predictor of prognosis in patients with $\mathrm{PCa}$ (50). In the present study, amplification and overexpression of HER2 was demonstrated in patients with $\mathrm{PCa}$, which has previously been associated with cancer progression, a poor prognosis and development of androgen independency (51). HER2 status is routinely assigned using in situ hybridization to assess HER2 gene amplification, but interpretation of in situ hybridization results may be challenging in tumors with chromosome 17 polysomy or intratumoral genetic heterogeneity. Apparent chromosome 17 polysomy, defined by increased CEP17 signal number, is a common genetic aberration in breast cancer and represents an alternative mechanism for increasing HER2 copy number. Elevated CEP17 count (polysomy) has been linked with adverse clinicopathologic features and HER2 overexpression, although there are numerous discrepancies in the literature (37). HER2 overexpression and/or amplification are recurrently reported in numerous tumor types, and have been shown to have significant therapeutic implications in patients with cancer (33). A meta-analysis of 5,976 patients demonstrated that HER2/neu overexpression was associated with mortality and recurrence in patients with PCa (52). Furthermore, it has been suggested that HER2 overexpression at the protein level is significantly associated with the amplification of HER2 (53). FISH is considered the gold standard method for detecting gene amplification, and has been reported to be more accurate than flow cytometry and immunohistochemistry (54). An increasing number of authors have employed the CISH method for determining gene amplification in various types of cancer $(37,55,56)$. CISH is a recently developed technique in which the DNA probe is located based on an immunoperoxidase reaction. This method is similar to FISH, although it does not involve the use of fluorescence microscopy. In addition, FISH signals fade within a few weeks and the FISH results must be recorded using 
expensive digital systems, which is not required for CISH staining. Owing to its resemblance to immunohistochemistry staining (57), CISH is also easier to interpret by pathologists who are not trained in fluorescence microscopy. Furthermore, in previous studies, CISH was observed to be well-correlated with FISH (46,58-60).

The present study used standard CISH to demonstrate that HER2 was amplified in Iranian (Tehran province) patients with PCa. Notably, HER2 amplification was observed in $>50 \%$ of patients. Similarly, using a FISH technique, a study on 44 patients with PCa demonstrated 53 and $80 \%$ low copy amplification in non-metastatic and metastatic samples, respectively (61). The results of the present study were consistent with previous studies, in which HER2 amplification was reported in 44 and $41 \%$ of 62 and 113 Americans, respectively, using the FISH method $(54,62)$, whereas another analysis reported no HER2 amplification (63). Furthermore, in a previous study, FFPE tissue blocks from 88 patients demonstrated a minor amplification rate of $9.3 \%$ (8/88 cases) (64). Similarly, Qi et al (53) used a FISH method and demonstrated that only $5.8 \%$ of Chinese patients with PCa had such a genetic alteration, and an investigation of 93 cancer samples showed that $6.5 \%$ had low levels of HER2 amplification, which was co-amplified with the topoisomerase (DNA) II $\alpha$ gene (65). These conflicting results may exist due to variation in the sample size and method used, or as a result of genetic heterogeneity. Furthermore, the findings may suggest that the CISH method is superior to FISH for HER2 detection in PCa samples. CISH has also been utilized for detection of copy number variation in the HER2/neu gene (66). In addition, the accuracy and reproducibility of CISH has been demonstrated in a previous study of breast carcinoma, in which the authors suggested that CISH may be regarded as a practical alternative for FISH (67). Other studies have considered this matter and proposed that CISH is a viable alternative to FISH and had similar properties; for example, both are in situ hybridization techniques and directly visualise the number of gene copies present in the nucleus, but CISH is cheaper and it produces a stable record of the slide that can be interpreted with a light microscope in the background of the tumour histopathology (68). Permanent staining and the absence of a fluorescent dye make CISH a suitable replacement for FISH (69). In addition, its usability, relative inexpensiveness and speed make CISH more attractive than FISH for assessing HER2 amplification/overexpression (59,70).

In conclusion, to the best of our knowledge, the present study is the first to report the amplification of HER2 in Iranian patients (Tehran province) with PCa. Furthermore, it was demonstrated that there were no associations among the serum levels of PSA, green/red ratios or Gleason scores in patients without HER2 amplification. Conversely, there was a weak correlation between the green/red ratio and age in these patients $(\mathrm{P}=0.046)$, which suggested the tendency for younger patients to exhibit lower levels of HER2 amplification. Notably, there was no association between the green/red ratio and pathologic stage of patients without HER2 amplification $(\mathrm{P}=0.873)$, although the increasing trend suggested that clinicians may consider Herceptin as a drug of choice for patients with PCa. In addition, there was no association between PSA levels $(\mathrm{P}=0.749)$ or Gleason score $(\mathrm{P}=0.057)$ and pathologic stage in patients without HER2 amplification. In patients with HER2 amplification, there was a significant association between the Gleason score and the serum level of PSA $(\mathrm{P}<0.001)$. However, there was no significant association between the other parameters in patients with HER2 amplification $(\mathrm{P}>0.05)$. The tumor position was not significantly associated with the mean age, PSA level, green/red ratio or Gleason score of the patients with HER2 amplification, although a significant correlation was observed between the Gleason score and pathological stage $(\mathrm{P}=0.002$; Table $\mathrm{V})$. Finally, the present study confirmed the results of previous studies, which suggested that the CISH method may be considered a valuable replacement for FISH. Further studies involving PCa samples are required in order to validate the results of the present study.

\section{Acknowledgements}

The present study was supported by a research grant from Tehran University of Medical Sciences (Tehran, Iran; 516478).

\section{References}

1. Braga-Basaria M, Dobs AS, Muller DC, Carducci MA, John M, Egan J and Basaria S: Metabolic syndrome in men with prostate cancer undergoing long-term androgen-deprivation therapy. J Clin Oncol 24: 3979-3983, 2006.

2. Perner S, Mosquera JM, Demichelis F, Hofer MD, Paris PL, Simko J, Collins C, Bismar TA, Chinnaiyan AM, De Marzo AM and Rubin MA: TMPRSS2-ERG fusion prostate cancer: An early molecular event associated with invasion. Am J Surg Pathol 31: 882-888, 2007.

3. Kolahdoozan S, Sadjadi A, Radmard AR and Khademi H: Five common cancers in Iran. Arch Iran Med 13: 143-146, 2010.

4. Center MM, Jemal A, Lortet-Tieulent J, Ward E, Ferlay J, Brawley $\mathrm{O}$ and Bray $\mathrm{F}$ : International variation in prostate cancer incidence and mortality rates. Eur Urol 61: 1079-1092, 2012.

5. Wong MC, Goggins WB, Wang HH, Fung FD, Leung C, Wong SY, Ng CF and Sung JJ: Global incidence and mortality for prostate cancer: Analysis of temporal patterns and trends in 36 countries. Eur Urol: June 8, 2016 (Epub ahead of print).

6. Kallioniemi OP and Visakorpi T: Genetic basis and clonal evolution of human prostate cancer. Adv Cancer Res 68: 225-255, 1996.

7. Boyd LK, Mao X and Lu YJ: The complexity of prostate cancer: Genomic alterations and heterogeneity. Nat Rev Urol 9: 652-664, 2012.

8. Heidenreich A, Bellmunt J, Bolla M, Joniau S, Mason M, Matveev V, Mottet N, Schmid HP, van der Kwast T, Wiegel T, et al: EAU guidelines on prostate cancer. Part 1: Screening, diagnosis, and treatment of clinically localised disease. Eur Urol 59: 61-71, 2011.

9. Damaschke N, Yang B, Bhusari S, Svaren J, Jarrard D. Epigenetic susceptibility factors for prostate cancer with aging. The Prostate. 2013;73(16): 1721-30

10. Parent ME and Siemiatycki J. Occupation and prostate cancer. Epidemiol Rev 23: 138-143, 2015.

11. Salmaninejad A, Sadeghi N, Ghadami S. Alterations of KRAS exon 2 codon 12/13 mutation status in prostatic adenocarcinoma; Bioinformatics aspects. Arch Can Res 4: 2, 2016.

12. Shen MM and Abate-Shen C: Molecular genetics of prostate cancer: New prospects for old challenges. Genes Dev 24: 1967-2000, 2010.

13. Eeles RA, Al Olama AA, Benlloch S, Saunders EJ, Leongamornlert DA, Tymrakiewicz M, Ghoussaini M, Luccarini C, Dennis J, Jugurnauth-Little S, et al: Identification of 23 new prostate cancer susceptibility loci using the iCOGS custom genotyping array. Nat Genet 45: 385-391, 391e1-2, 2013.

14. Takata R, Akamatsu S, Kubo M, Takahashi A, Hosono N, Kawaguchi T, Tsunoda T, Inazawa J, Kamatani N, Ogawa O, et al: Genome-wide association study identifies five new susceptibility loci for prostate cancer in the Japanese population. Nat Genet 42: 751-754, 2010. 
15. Barbieri CE, Demichelis F and Rubin MA: Molecular genetics of prostate cancer: Emerging appreciation of genetic complexity. Histopathology 60: 187-198, 2012.

16. Tomlins SA, Laxman B, Dhanasekaran SM, Helgeson BE, Cao X, Morris DS, Menon A, Jing X, Cao Q, Han B, et al: Distinct classes of chromosomal rearrangements create oncogenic ETS gene fusions in prostate cancer. Nature 448: 595-599, 2007.

17. Kumar-Sinha C, Tomlins SA and Chinnaiyan AM: Recurrent gene fusions in prostate cancer. Nat Rev Cancer 8: 497-511, 2008.

18. Santarius T, Shipley J, Brewer D, Stratton MR and Cooper CS: A census of amplified and overexpressed human cancer genes. Nat Rev Cancer 10: 59-64, 2010.

19. Salmaninejad A, Ghadami S, Dizaji MZ, Golchehre Z, Estiar MA, Zamani MR, Ebrahimzadeh-Vesal R, Nowroozi MR and Shakoori A: Molecular characterization of KRAS, BRAF, and EGFR genes in cases with prostatic adenocarcinoma; reporting bioinformatics description and recurrent mutations. Clin Lab 61: 749-759, 2015.

20. Brown RS, Edwards J, Dogan A, Payne H, Harland SJ, Bartlett JM and Masters JR: Amplification of the androgen receptor gene in bone metastases from hormone-refractory prostate cancer. J Pathol 198: 237-244, 2002.

21. Saramäki OR, Tammela TL, Martikainen PM, Vessella RL and Visakorpi T: The gene for polycomb group protein enhancer of zeste homolog 2 (EZH2) is amplified in late-stage prostate cancer. Genes Chromosomes Cancer 45: 639-645, 2006.

22. Saramäki O, Willi N, Bratt O, Gasser TC, Koivisto $P$, Nupponen NN, Bubendorf L and Visakorpi T: Amplification of EIF3S3 gene is associated with advanced stage in prostate cancer. Am J Pathol 159: 2089-2094, 2001.

23. Bloch M, Ousingsawat J, Simon R, Schraml P, Gasser TC, Mihatsch MJ, Kunzelmann K and Bubendorf L: KCNMA1 gene amplification promotes tumor cell proliferation in human prostate cancer. Oncogene 26: 2525-2534, 2007

24. Ren B, Yu G, Tseng GC, Cieply K, Gavel T, Nelson J, Michalopoulos G, Yu YP and Luo JH: MCM7 amplification and overexpression are associated with prostate cancer progression. Oncogene 25: 1090-1098, 2006.

25. Wang R, Xu J, Saramäki O, Visakorpi T, Sutherland WM, Zhou J, Sen B, Lim SD, Mabjeesh N, Amin M, et al: PrLZ, a nove prostate-specific and androgen-responsive gene of the TPD52 family, amplified in chromosome 8q21. 1 and overexpressed in human prostate cancer. Cancer Res 64: 1589-1594, 2004.

26. Saramäki OR, Savinainen KJ, Nupponen NN, Bratt O and Visakorpi T: Amplification of hypoxia-inducible factor 1alpha gene in prostate cancer. Cancer Genet Cytogenet 128: 31-34, 2001.

27. Rimawi MF, Mayer IA, Forero A, Nanda R, Goetz MP, Rodriguez AA, Pavlick AC, Wang T, Hilsenbeck SG, et al: Multicenter phase II study of neoadjuvant lapatinib and trastuzumab with hormonal therapy and without chemotherapy in patients with human epidermal growth factor receptor 2-overexpressing breast cancer: TBCRC 006. J Clin Oncol 31: 1726-1731, 2013.

28. Cobleigh MA, Vogel CL, Tripathy D, Robert NJ, Scholl S, Fehrenbacher L, Wolter JM, Paton V, Shak S, Lieberman G and Slamon DJ: Multinational study of the efficacy and safety of humanized anti-HER2 monoclonal antibody in women who have HER2-overexpressing metastatic breast cancer that has progressed after chemotherapy for metastatic disease. J Clin Oncol 17: 2639-2648, 1999

29. Poovassery JS, Kang JC, Kim D, Ober RJ and Ward ES: Antibody targeting of HER2/HER3 signaling overcomes heregulin-induced resistance to PI3K inhibition in prostate cancer. Int J Cancer 137: 267-277, 2015

30. Rao K, Gaughan L, Robson $\mathrm{C}$ and McCracken $\mathrm{S}$ : The role of the HER 2 and HER3 in prostate cancer and their potential as therapeutic targets. Eur J Cancer 61: S177-S178, 2016.

31. Baek KH, Hong ME, Jung YY, Lee CH, Lee TJ, Park ES, Kim MK, Yoo JH and Lee SW: Correlation of AR, EGFR, and HER2 expression levels in prostate cancer: Immunohistochemical analysis and chromogenic in situ hybridization. Cancer Res Treat 44: 50-56, 2012.

32. Reese DM, Small EJ, Magrane G, Waldman FM, Chew K and Sudilovsky D: HER2 protein expression and gene amplification in androgen-independent prostate cancer. Am J Clin Pathol 116 234-239, 2001.

33. Yan M, Schwaederle M, Arguello D, Millis SZ, Gatalica Z and Kurzrock R: HER2 expression status in diverse cancers: Review of results from 37,992 patients. Cancer Metastasis Rev 34 $157-164,2015$.
34. Yamanaka Y, Friess H, Kobrin MS, Büchler M, Kunz J, Beger HG and Korc M: Overexpression of HER2/neu oncogene in human pancreatic carcinoma. Hum Pathol 24: 1127-1134, 1993.

35. Nuciforo PG, Pellegrini C, Fasani R, Maggioni M, Coggi G, Parafioriti A and Bosari S: Molecular and immunohistochemical analysis of HER 2/neu oncogene in synovial sarcoma. Hum Pathol 34: 639-645, 2003

36. Salmaninejad A, Estiar MA, Gill RK, Shih JH, Hewitt S, Jeon HS, Fukuoka J, Shilo K, Shakoori A and Jen J: Expression analysis of p16, c-Myc, and $\mathrm{mSin} 3 \mathrm{~A}$ in non-small cell lung cancer by computer aided scoring and analysis (CASA). Clin Lab 61: 549-559, 2015.

37. Hanna WM, Rüschoff J, Bilous M, Coudry RA, Dowsett M, Osamura RY, Penault-Llorca F, van de Vijver M and Viale G: HER2 in situ hybridization in breast cancer: clinical implications of polysomy 17 and genetic heterogeneity. Mod Pathol 27: 4-18, 2014.

38. Bar-Shira A, Pinthus JH, Rozovsky U, Goldstein M, Sellers WR, Yaron Y, Eshhar Z and Orr-Urtreger A: Multiple genes in human $20 \mathrm{q} 13$ chromosomal region are involved in an advanced prostate cancer xenograft. Cancer Res 62: 6803-6807, 2002.

39. Sattler HP, Lensch R, Rohde V, Zimmer E, Meese E, Bonkhoff H, Retz M, Zwergel T, Bex A, Stoeckle M and Wullich B: Novel amplification unit at chromosome $3 \mathrm{q} 25-\mathrm{q} 27$ in human prostate cancer. Prostate 45: 207-215, 2000.

40. Elo JP and Visakorpi T: Molecular genetics of prostate cancer. Ann Med 33: 130-141, 2001.

41. Edwards J, Mukherjee R, Munro AF, Wells AC, Almushatat A and Bartlett JM: HER 2 and COX2 expression in human prostate cancer. Eur J Cancer 40: 50-55, 2004.

42. Edwards J, Krishna NS, Witton CJ and Bartlett JM: Gene amplifications associated with the development of hormone-resistant prostate cancer. Clin Cancer Res 9: 5271-2581, 2003.

43. Nupponen NN, Kakkola L, Koivisto P and Visakorpi T: Genetic alterations in hormone-refractory recurrent prostate carcinomas. Am J Pathol 153: 141-148, 1998.

44. Lass U, Hartmann C, Capper D, Herold-Mende C, von Deimling A, Meiboom $\mathrm{M}$ and Mueller W: Chromogenic in situ hybridization is a reliable alternative to fluorescence in situ hybridization for diagnostic testing of $1 p$ and $19 q$ loss in paraffin-embedded gliomas. Brain Pathol 23: 311-318, 2013.

45. Zhang Y, Perez T, Blondin B, Du J, Liu P, Escarzaga D, et al. Identification of FISH biomarkers to detect chromosome abnormalities associated with prostate adenocarcinoma in tumour and field effect environment. BMC Cancer 14: 129, 2014.

46. Arnould L, Denoux Y, MacGrogan G, Penault-Llorca F, Fiche M, Treilleux I, Mathieu MC, Vincent-Salomon A, Vilain MO and Couturier J: Agreement between chromogenic in situ hybridisation (CISH) and FISH in the determination of HER2 status in breast cancer. Br J Cancer 88: 1587-1591, 2003.

47. Brimo F1, Montironi R, Egevad L, Erbersdobler A, Lin DW, Nelson JB, Rubin MA, van der Kwast T, Amin M and Epstein JI: Contemporary grading for prostate cancer: Implications for patient care. Eur Urol 63: 892-901, 2013

48. Heidenreich A1, Bastian PJ, Bellmunt J, Bolla M, Joniau S, van der Kwast T, Mason M, Matveev V, Wiegel T, Zattoni F and Mottet N; European Association of Urology: EAU guidelines on prostate cancer. Part 1: Screening, diagnosis, and local treatment with curative intent - update 2013. Eur Urol 65: 124-137, 2014.

49. Tanner M, Gancberg D, Di Leo A, Larsimont D, Rouas G, Piccart MJ and Isola J: Chromogenic in situ hybridization: A practical alternative for fluorescence in situ hybridization to detect HER-2/neu oncogene amplification in archival breast cancer samples. Am J Pathol 157: 1467-1472, 2000

50. Lennartz M, Minner S, Brasch S, Wittmann H, Paterna L, Angermeier K, Öztürk E, Shihada R, Ruge M, Kluth M, et al: The combination of DNA ploidy status and PTEN/6q15 deletions provides strong and independent prognostic information in prostate cancer. Clin Cancer Res 22: 2802-2811, 2016

51. Di Lorenzo G, Tortora G, D'Armiento FP, De Rosa G, Staibano S, Autorino R, D'Armiento M, De Laurentiis M, De Placido S, Catalano G, et al: Expression of epidermal growth factor receptor correlates with disease relapse and progression to androgen-independence in human prostate cancer. Clin Cancer Res 8: 3438-3444, 2002

52. Neto AS, Tobias-Machado M, Wroclawski ML, Fonseca FL, Teixeira GK, Amarante RD, Wroclawski ER and Del Giglio A: Her-2/neu expression in prostate adenocarcinoma: A systematic review and meta-analysis. J Urol 184: 842-850, 2010. 
53. Qi M, Yang X, Zhang F, Lin T, Sun X, Li Y, Yuan H, Ren Y, Zhang J, Qin X and Han B: ERG rearrangement is associated with prostate cancer-related death in Chinese prostate cancer patients. PLoS One 9: e84959, 2014.

54. Ross JS, Sheehan C, Hayner-Buchan AM, Ambros RA, Kallakury BV, Kaufman R, Fisher HA and Muraca PJ: HER-2/neu gene amplification status in prostate cancer by fluorescence in situ hybridization. Hum Pathol 28: 827-833, 1997.

55. Valtorta E, Misale S, Sartore-Bianchi A, Nagtegaal ID, Paraf F, Lauricella C, Dimartino V, Hobor S, Jacobs B, Ercolani C, et al KRAS gene amplification in colorectal cancer and impacton response to EGFR-targeted therapy. Int J Cancer 133: 1259-1265, 2013.

56. Park YS, Hwang HS, Park HJ, Ryu M-H, Chang H-M, Yook JH, Kim BS, Jang SJ and Kang YK: Comprehensive analysis of HER2 expression and gene amplification in gastric cancers using immunohistochemistry and in situ hybridization: Which scoring system should we use? Hum Pathol 43: 413-422, 2012.

57. Jacquemier J, Spyratos F, Esterni B, Mozziconacci M-J, Antoine M, Arnould L, Lizard S, Bertheau P, Lehmann-Che J, Fournier CB, et al: SISH/CISH or qPCR as alternative techniques to FISH for determination of HER2 amplification status on breast tumors core needle biopsies: A multicenter experience based on 840 cases. BMC Cancer 13: 351, 2013

58. Horii R, Matsuura M, Iwase T, Ito Y and Akiyama F: Comparison of dual-color in-situ hybridization and fluorescence in-situ hybridization in HER2 gene amplification in breast cancer. Breast Cancer 21:598-604, 2014.

59. Rosa FE, Santos RM, Rogatto SR and Domingues MA: Chromogenic in situ hybridization compared with other approaches to evaluate HER2/neu status in breast carcinomas. Braz J Med Biol Res 46: 207-216, 2013.

60. Kiyose S, Igarashi H, Nagura K, Kamo T, Kawane K, Mori H, Ozawa T, Maeda M, Konno K, Hoshino H, et al: Chromogenic in situ hybridization (CISH) to detect HER2 gene amplification in breast and gastric cancer: comparison with immunohistochemistry (IHC) and fluorescence in situ hybridization (FISH). Pathol Int 62: 728-734, 2012.

61. Liu HL, Gandour-Edwards R, Lara PN Jr, de Vere White R and LaSalle JM: Detection of low level HER-2/neu gene amplification in prostate cancer by fluorescence in situ hybridization. Cancer J 7: 395-403, 2001.
62. Ross JS, Sheehan CE, Hayner-Buchan AM, Ambros RA, Kallakury BV, Kaufman RP Jr, Fisher HA, Rifkin MD and Muraca PJ: Prognostic significance of HER-2/neu gene amplification status by fluorescence in situ hybridization of prostate carcinoma. Cancer 79: 2162-2170, 1997.

63. Sadasivan R, Morgan R, Jennings S, Austenfeld M, Van Veldhuizen P, Stephens R and Noble M: Overexpression of Her-2/neu may be an indicator of poor prognosis in prostate cancer. J Urol 150: 126-131, 1993.

64. Mark HF, Feldman D, Das S, Kye H, Mark S, Sun CL and Samy M: Fluorescence in situ hybridization study of HER-2/neu oncogene amplification in prostate cancer. Exp Mol Pathol 66: 170-178, 1999.

65. Murphy AJ, Hughes CA, Barrett C, Magee H, Loftus B, O'Leary JJ and Sheils O: Low-level TOP2A amplification in prostate cancer is associated with HER 2 duplication, androgen resistance, and decreased survival. Cancer Res 67: 2893-2898, 2007.

66. Savinainen KJ, Saramäki OR, Linja MJ, Bratt O, Tammela TL, Isola JJ and Visakorpi T: Expression and gene copy number analysis of ERBB2 oncogene in prostate cancer. Am J Pathol 160: 339-345, 2002

67. Loring P, Cummins R, O'Grady A and Kay EW: HER2 positivity in breast carcinoma: A comparison of chromogenic in situ hybridization with fluorescence in situ hybridization in tissue microarrays, with targeted evaluation of intratumoral heterogeneity by in situ hybridization. Appl Immunohistochem Mol Morphol 13: 194-200, 2005.

68. van de Vijver M, Bilous M, Hanna W, Hofmann M, Kristel P, Penault-Llorca F and Rüschoff J: Chromogenic in situ hybridisation for the assessment of HER2 status in breast cancer: An international validation ring study. Breast Cancer Res 9: R68, 2007.

69. Elliott K, Hamilton PW and Maxwell P: Fluorescence (FISH) and chromogenic (CISH) in situ hybridisation in prostate carcinoma cell lines: Comparison and use of virtual microscopy. Br J Biomed Sci 65: 167-171, 2008.

70. Penault-Llorca F, Bilous M, Dowsett M, Hanna W, Osamura RY, Rüschoff J and van de Vijver M: Emerging technologies for assessing HER2 amplification. Am J Clin Pathol 132: 539-548, 2009. 